\title{
Sustainable agriculture undergraduate degree programs: A land-grant university mission
}

Krista L. Jacobsen, ${ }^{a}$ * Department of Horticulture, University of Kentucky

Kim L. Niewolny, ${ }^{b}$ Department of Agricultural and Extension Education, Virginia Tech

Michelle S. Schroeder-Moreno, ${ }^{c}$ Department of Crop Science, North Carolina State University

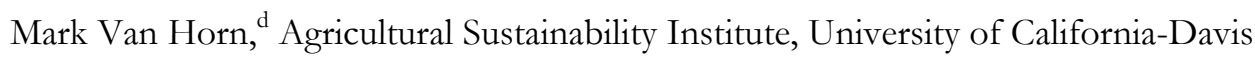

Alison H. Harmon, e' Department of Health and Human Development, Montana State University

Yolanda H. Chen Fanslow, ${ }^{\mathrm{f}}$ Department of Plant and Soil Science, University of Vermont

Mark A. Williams, ${ }^{g}$ Department of Horticulture, University of Kentucky

Damian Parr, ${ }^{\text {h }}$ Sustainable Agriculture Education Association

Submitted 6 December 2011 / Revised 17 February 2012 / Accepted 2 March 2012 / Published online 27 May 2012

Citation: Jacobsen, K. L., Niewolny, K. L., Schroeder-Moreno, M. S., Van Horn, M., Harmon, A. H., Chen Fanslow, Y. H., Williams, M. A., \& Parr, D. (2012). Sustainable agriculture undergraduate degree programs: A land-grant university mission. Journal of Agriculture, Food Systems, and Community Development, 2(3), 13-26. http://dx.doi.org/10.5304/jafscd.2012.023.004

Copyright (C) 2012 by New Leaf Associates, Inc.

a, * Corresponding author: Krista L. Jacobsen, N-310C Agricultural Sciences North, University of Kentucky, Lexington, KY 40546 USA; +1-859-257-3921; krista.jacobsen@uky.edu

b 282 Litton Reaves Hall, Department of Agricultural and Extension Education, Virginia Tech, Blacksburg, VA 24061 USA; + 1-540-231-5784; niewolny@,vt.edu

c 2406 Williams Hall, Department of Crop Science, NC State University, Raleigh, NC 27695 USA; +1-919-513-0085; michelle_schroeder@ncsu.edu

d Agricultural Sustainability Institute, 143 Robbins Hall, University of California, Davis, CA 95616 USA; +1-530-752-

7645; mxvanhorn@ucdavis.edu

e 201A Romney Gym; Montana State University; Bozeman, MT 59717-3360; +1-406-994-6338; harmon@montana.edu

${ }^{\mathrm{f}}$ Jeffords Hall, 63 Carrigan Drive, Univ of Vermont, Burlington, VT 05405 USA; +1-802-656-9828; volanda.chen@uvm.edu

g N-322D Agricultural Sciences North, University of Kentucky, Lexington, KY 40546 USA; +1-859-257-2638; mark.williams@,uky.edu

h http://sustainableaged.org/ ; dmparr@ucdavis.edu

\begin{abstract}
There has been considerable growth in the number undergraduate degree programs in sustainable agriculture $(\mathrm{SA})$ in universities and colleges across the country in the past 25 years. As a subset of this national trend, land-grant universities (LGUs) are emerging as catalysts in innovative SA program development, in part due to the LGU tripartite mission of education, extension, and research. This mission compels LGUs to develop undergraduate degree offerings to engage student, faculty, and community stakeholders who are increasingly interested in SA. In this article, which is an outcome of a gathering of faculty, staff and students from SA programs at LGUs at a workshop prior to the 4th
\end{abstract}

Disclosure: Krista Jacobsen, Kim Niewolny, Michelle Schroeder-Moreno, and Damian Parr currently serve on the steering council of the Sustainable Agriculture Education Association, which cersityonvened the meeting that inspired this paper. They do not receive any compensation for these roles and have no financial interest in the SAEA. 
National Sustainable Agriculture Education Association Conference in August 2011, we discuss the justification for SA programming at LGUs, the emergence of SA major and minor degrees at 11 LGUs to date, the common successes and challenges of current SA programs, strategies for improving existing SA programming, and systematic approaches for expanding SA education impact across institutional lines. We also introduce several additional topic-based articles that resulted from workshop dialogue that appear in this issue of the Journal of Agriculture, Food Systems, and Community Development, including civic engagement efforts in SA education through community-university partnerships, a critical documentation of the implicit inclusion of values into SA education, and efforts to internationalize SA curriculum.

\section{Keywords}

experiential education, Higher Education Challenge Grant, interdisciplinary education, land-grant universities, sustainable agriculture education

\section{Introduction}

Over the past 25 years, there has been considerable growth of sustainable agriculture (SA) education programs in universities and colleges nationwide (United States Department of Agriculture [USDA], 2009). The growing numbers of SA students and educators is further demonstrated-by the development of a new Sustainable Agriculture Education Association (SAEA). The SAEA emerged in 2006 in part to fulfill the need for an organization that focused specifically on supporting and sharing SA education curricula for both teachers and learners (SAEA, n.d.-a). The SAEA has produced four national biannual conferences, which are the sole national-level forum for faculty, staff, students, and community-based practitioners to connect on matters of teaching and learning in sustainable agriculture. Attendance has grown with each conference, with representation from educators, and both undergraduate and graduate students from SA programs at colleges and universities across the country. As a subset of this larger national trend, land-grant universities (LGUs) across the country are emerging as catalysts for developing innovative SA educational programs for a variety of reasons. These include but are not limited to the unique triad mission of LGUs that focus on education, research and extension; growing student interest in sustainable agriculture and food systems; and new faculty and staff hires.

In an effort to bring programs at LGUs together for an extended, focused dialogue, a preconference workshop was held at the University of Kentucky in Lexington on August 3, 2011, in conjunction with the $4^{\text {th }}$ National SAEA Conference. This full-day, facilitated workshop brought faculty and students together to discuss the "State of Sustainable Agriculture Education at Land-Grant Universities," specifically focusing on identifying national needs in SA programming at LGUs and sharing the successes, challenges, and current program state and structure at participating institutions. Six universities were represented (Michigan State University, North Carolina State University, University of California-Davis, University of Kentucky, University of Missouri, and Virginia Tech), with one to three faculty members and several undergraduate students from each of the participating programs.

Workshop invitees were representatives of major and/or minor undergraduate degree programs in SA, as identified through the SAEA programs website (SAEA, n.d.-b) and the National Agriculture Library list of programs (USDA, 2009). This boundary of major and minor programs only (i.e., excluding concentrations, specializations, certificates, etc.) was delineated for the purposes of convening a cohesive cohort of programs that are structured administratively in similar ways and have been approved fully on the university level (see table 1). Many of the specific program names differ and therefore emphasize various components of SA education, such as agroecology, organic agriculture, and sustainable food systems. For the purpose of the workshop, and this paper, we collectively refer to them as sustainable agriculture (SA) programs because they share similar interdisciplinary, agriculture and food systems-based curricula that emphasize experiential teaching and learning approaches (Francis, Jordan, Porter, Breland, Lieblein, Salomonsson,... Langer, 2011; Francis, Leiblein, Helenius, Salomonsson, Olsen, Porter, 2001; Parr, Trexler, Khanna, \& Battisti, 
Table 1. Programmatic Information for the Sustainable Agriculture Degree Programs Included in this Work, with Key Supporting Resources Used To Create Curricula

\begin{tabular}{|c|c|c|c|c|c|c|c|}
\hline $\begin{array}{l}\text { Land Grant } \\
\text { University }\end{array}$ & Program Name ${ }^{2}$ & Degree & $\begin{array}{c}\text { Year } \\
\text { Established }\end{array}$ & $\begin{array}{l}\text { Student } \\
\text { Farm? }\end{array}$ & $\begin{array}{l}\text { New or } \\
\text { Replace } \\
\text { Existing } \\
\text { Major? }\end{array}$ & $\begin{array}{l}\text { External } \\
\text { Funding Sources } \\
\text { for Program } \\
\text { Creation }\end{array}$ & $\begin{array}{c}\text { Community } \\
\text { Stakeholder } \\
\text { Input into SA } \\
\text { Program Process }\end{array}$ \\
\hline $\begin{array}{l}\text { Montana State } \\
\text { University }\end{array}$ & $\begin{array}{l}\text { Sustainable Food } \\
\text { \& Bioenergy } \\
\text { Systems }\end{array}$ & B.S. Major & 2009 & Yes & New & HECGe & Advisory panel \\
\hline $\begin{array}{l}\text { North Carolina } \\
\text { State University }\end{array}$ & Agroecology & Minor ${ }^{3}$ & 2004 & $\begin{array}{l}\text { In develop- } \\
\text { mentc }\end{array}$ & New & HECGe & $\begin{array}{c}\text { Multilevel, } \\
\text { multi-institution } \\
\text { collaborations }\end{array}$ \\
\hline $\begin{array}{l}\text { The Pennsylvania } \\
\text { State University }\end{array}$ & ${ }^{\text {a }}$ Agroecology & B.S. Major & ca. 1997 & No & $\begin{array}{l}\text { Replace } \\
\text { Existing }\end{array}$ & None & $\begin{array}{l}\text { Stakeholder } \\
\text { survey }\end{array}$ \\
\hline $\begin{array}{l}\text { University of } \\
\text { California- Davis }\end{array}$ & $\begin{array}{l}\text { Sustainable } \\
\text { Agriculture \& } \\
\text { Food Systems }\end{array}$ & B.S. Major & 2011 & Yes & New & $\begin{array}{l}\text { Foundation } \\
\text { funds }{ }^{f}\end{array}$ & $\begin{array}{l}\text { Delphi study; } \\
\text { advisory panel }\end{array}$ \\
\hline $\begin{array}{l}\text { University of } \\
\text { Florida }\end{array}$ & $\begin{array}{l}\text { Organic \& } \\
\text { Sustainable Crop } \\
\text { Production }\end{array}$ & Minorb & 2006 & $\mathrm{No}^{d}$ & New & None & $\begin{array}{l}\text { Informal } \\
\text { interviews }\end{array}$ \\
\hline $\begin{array}{l}\text { University of } \\
\text { Kentucky }\end{array}$ & $\begin{array}{l}\text { Sustainable } \\
\text { Agriculture }\end{array}$ & $\begin{array}{l}\text { B.S. Major, } \\
\text { Minor }\end{array}$ & 2007 & Yes & New & HECGe & $\begin{array}{l}\text { Informal } \\
\text { interviews }\end{array}$ \\
\hline $\begin{array}{l}\text { University of } \\
\text { Maine }\end{array}$ & $\begin{array}{l}\text { Sustainable } \\
\text { Agriculture }\end{array}$ & B.S. Major & 1988 & Yes & New & None & $\begin{array}{c}\text { Informal } \\
\text { interviews }\end{array}$ \\
\hline $\begin{array}{l}\text { University of } \\
\text { Missouri }\end{array}$ & $\begin{array}{l}\text { Sustainable } \\
\text { Agriculture }\end{array}$ & Minorb & 2002 & No & New & HECGe & $\begin{array}{c}\text { Informal } \\
\text { interviews }\end{array}$ \\
\hline $\begin{array}{l}\text { University of } \\
\text { Vermont }\end{array}$ & $\begin{array}{l}\text { Ecological } \\
\text { Agriculture }\end{array}$ & $\begin{array}{l}\text { B.S. Major, } \\
\text { Minor }\end{array}$ & 2004 & Yes & New & None & $\begin{array}{l}\text { Informal } \\
\text { interviews }\end{array}$ \\
\hline $\begin{array}{l}\text { University of } \\
\text { Wyoming }\end{array}$ & Agroecology & $\begin{array}{l}\text { B.S. Major, } \\
\text { Minor }\end{array}$ & 1993 & Yes & $\begin{array}{l}\text { Replace } \\
\text { Existing }\end{array}$ & None & $\begin{array}{l}\text { Informal } \\
\text { interviews }\end{array}$ \\
\hline Virginia Tech & $\begin{array}{l}\text { Civic Agriculture } \\
\& \text { Food Systems }\end{array}$ & Minor & 2010 & $\begin{array}{c}\text { In } \\
\text { development }\end{array}$ & New & HECGe & $\begin{array}{l}\text { Community } \\
\text { task force }\end{array}$ \\
\hline
\end{tabular}

Data from this table were populated from the National Agriculture Library database, the Sustainable Agriculture Education Association website (http://www.sustainableaged.org), and program self-identification.

a Additional program information may be found on the contributing programmatic websites:

Montana State University: http://sfbs.montana.edu/

North Carolina State University: http://www.cropsci.ncsu.edu/agroecology/program.htm

The Pennsylvania State University: http://agroecology.psu.edu/index.cfm

University of California-Davis: http://Itras.ucdavis.edu/students/about-major

University of Florida: http://www.hos.ufl.edu/undergraduate-program/minors\#Organic

University of Kentucky: http://www2.ca.uky.edu/sustainableag/

University of Maine: http://sag.umaine.edu/

University of Missouri: http://cafnr.missouri.edu/academics/sustainable-ag.php

University of Vermont: http://www.uvm.edu/ pss/?Page=pssdeptweb/eadegree.htm

University of Wyoming: http://www.uwyo.edu/esm/undergraduate-programs/agroecology/

Virginia Tech: http://www.cals.vt.edu/students/undergraduate/minors/civic-ag.php

b The University of Florida also has major specializations under departmental or college-level umbrella degree programs.

c Students also have access to facility dedicated to sustainable agriculture research and outreach.

d Students have access to on-campus teaching gardens, although they are not considered a student farm.

e HECG = USDA Higher Education Challenge Grant

f Foundation funds were used to support program creation; HECG funds have been used for student recruitment.

g Collaborators on program development include a number of researchers, educators and extension specialists from educational institutions across North Carolina (Schroeder, Creamer, Linker, Mueller, \& Rzewnicki, 2006). 
2007). The starting point for this set of related papers in this issue of the Journal of Agriculture, Food Systems and Community Development focusing on the topic of higher education and food systems is our workshop dialogue, with efforts made to increase the robustness of this dialogue through inclusion of input from our colleagues at LGUs who were not able to attend the workshop. We recognize this cohort is certainly not representative of all SA programming at LGUs, or necessarily representative of the diversity of programs at higher education institutions across the country. For example, we recognize that there are some SA-oriented programs at LGUs that are structurally similar to those outlined here and, for various institutionspecific reasons, are characterized as "specializations," "certificates," etc. However, such terms are used in other ways at still other institutions, so we exclude these programs for the sake of consistency. Instead of casting a wider net, we chose to focus on this discreet cohort of programs to focus the dialogue and to better understand how the unique environment at LGUs both helps and hinders in creating degree offerings in SA, as well as to document our experiences in order to provide models and "lessons learned" for our colleagues at peer institutions and to encourage further development of SA programs at LGUs nationally. Further, we would be remiss to not recognize the foundational efforts of other institutions of higher education that have generously contributed to SA teaching and learning over the years (e.g., Appalachian State University, Berea College, College of the Atlantic, Evergreen State College, and University of California, Santa Cruz). Thus, our self-critical exploration and documentation aim to engender ongoing discussion within and among universities and colleges committed to SA programming.

In other articles in this volume, workshop participants and contributing authors discuss critical topics raised in the workshop dialogue, including efforts to civically engage the greater farming and food systems community in SA education efforts through sustained communityuniversity partnerships (Niewolny, Grossman, Byker, Helms, Clark, Cotton, \& Jacobsen, this issue), a critical documentation of the implicit inclusion of values into SA pedagogy (Galt, Clark,
Parr, this issue), and efforts to internationalize SA curriculum (Schroeder-Moreno, Clark, Byker, Zhao, this issue). In this introductory article, therefore, we discuss the justification for SA education programming at LGUs, the emergence of SA major and minor degrees to date, the common successes and challenges of current SA programs, and strategies for improving existing SA programming and expanding their impact.

\section{The Role of the LGU System}

The LGU system is a major contributor to publicly funded higher education because of its unique history of practical instruction to citizens of ordinary means (LaMay, 2001; Morrill Act, 1862; National Research Council [NRC], 1996). This orientation toward linking academics to real-world contexts and purposeful activities has direct links to John Dewey (1916) and other progressive educational philosophers who were engaged in the debates about educational reforms in nineteenthand early twentieth-century America. Before the founding of the LGU in 1862, postsecondary education in the U.S. was primarily focused on teaching classics to the elite. For nearly a century after its founding, the LGU served the applied agricultural needs of students, integrating both the scientific theory and practice of agriculture, making the curricula both relevant and accessible to the working classes.

The dominant educational philosophy and curricula of the LGU system has changed dramatically since its initial inception, and a number of studies from the 1990s (Boyer Commission, 1998; Kellogg Commission on the Future of State and Land-Grant Universities, 1999; NRC, 1996) began questioning the LGUs' performance in serving the needs of its mandated constituencies. These critiques called for transforming the status quo of LGU curricula and pedagogy, away from Ivory Tower, didactic teaching from the perspective of a single discipline, toward "innovative multidisciplinary and systems-based course materials and curricula" (NRC, 1996, p. 5). Ten years later the National Research Council report, "Transforming Agricultural Education for a Changing World” (2009), affirmed many of its earlier published concerns and recommendations, warning, "if 
institutions of higher learning do not address the changes needed, their colleges and departments of agriculture may eventually become irrelevant" (p. 4). These recent calls for a more integrated and engagement-oriented LGU and agricultural curriculum are a revival from the last century, when scholars in LGUs were inventing how best to educate students of agriculture in progressive ways. Our contemporary challenge and opportunity are to learn from this rich history and provide our students with "real-world" experiences that reflect the complexities of agriculture and food systems that graduates will face in their future careers.

LGUs play a lead role in educating the nation's future producers, agricultural scientists, policymakers, educators, and food system leaders. However, the obstacles to teaching and developing SA education programs at LGUs are significant (Altieri \& Francis, 1992). To date, SA programs are still few in comparison to traditional productionagriculture programs at LGUs. SA education grapples with the necessary shift in emphasis from teaching how to maximize production to teaching how to optimize for a suite of environmental, social, and economic objectives (Francis et al., 2003).

Despite the challenges, faculty from a number of LGUs have been leaders in developing SA education programs and collaborating across traditional departmental and disciplinary lines to create programs that seek to integrate the ecological, social, and economic factors in agricultural systems (table 1). These faculty have been collaborating and exchanging ideas broadly within and among institutions, but there have been few opportunities for faculty to share in the progress, successes, and challenges in these programs that are specifically operating within the LGU structure (for a notable exception, see Ngouajio, Delate, Carey, Azarenko, Ferguson, \& Sciarappa, 2006).

\section{The Emergence of SA Programs at LGUs}

Although there are a growing number of SA programs at LGUs in various states of curricular development, the emergence of each program is unique at each institution; that is, it reflects a function of the broader educational and political climate at each college of agriculture and university, as well as the personalities and local resources available at inter- and intra-departmental levels. Within our cohort of major and minor undergraduate programs in SA at LGUs, the unique stories and the relatively small number of SA programs makes developing typologies of the creation and current structure of degree programs difficult. However, through shared dialogue at the workshop, subsequent follow-up with faculty from additional programs, and a comprehensive literature review, a common pool of initial conditions and available resources were identified that have been integral to the creation of SA programs at LGUs.

The components in figure 1 represent the array of conditions and resources that were important in creating SA programs at the LGUs represented in this work. At each institution, the necessary components to program creation were (1) a window of opportunity for the creation of an SA program, (2) key players who provided the thrust of the work in program creation, and (3) a set of resources that key players utilized to provide support and legitimacy for SA program creation efforts. The specific nature of these components varies by institution, and figure 1 represents a diversity of examples of these components that were important in SA program creation at the LGUs represented in this work. We view this suite of conditions and resources as a programmatic "primordial soup" that represents necessary components of successful program creation when the opportunity arises for a new SA program to be developed. By documenting and discussing the general role of the conditions and resources that have been important in SA undergraduate curricula across the country, we aim to provide a general framework that captures the "creation stories" of all of our programs. Within this general framework, we offer some particular considerations for program creation within the LGU structure, to serve as both documentation and a guide for future program development at our peer institutions.

\section{SA Program Development Opportunities}

The SA programs represented in this work were initiated as a result of two types of programmatic 

Agriculture Undergraduate Degree Program Development at the Land Grant Universities in this Work

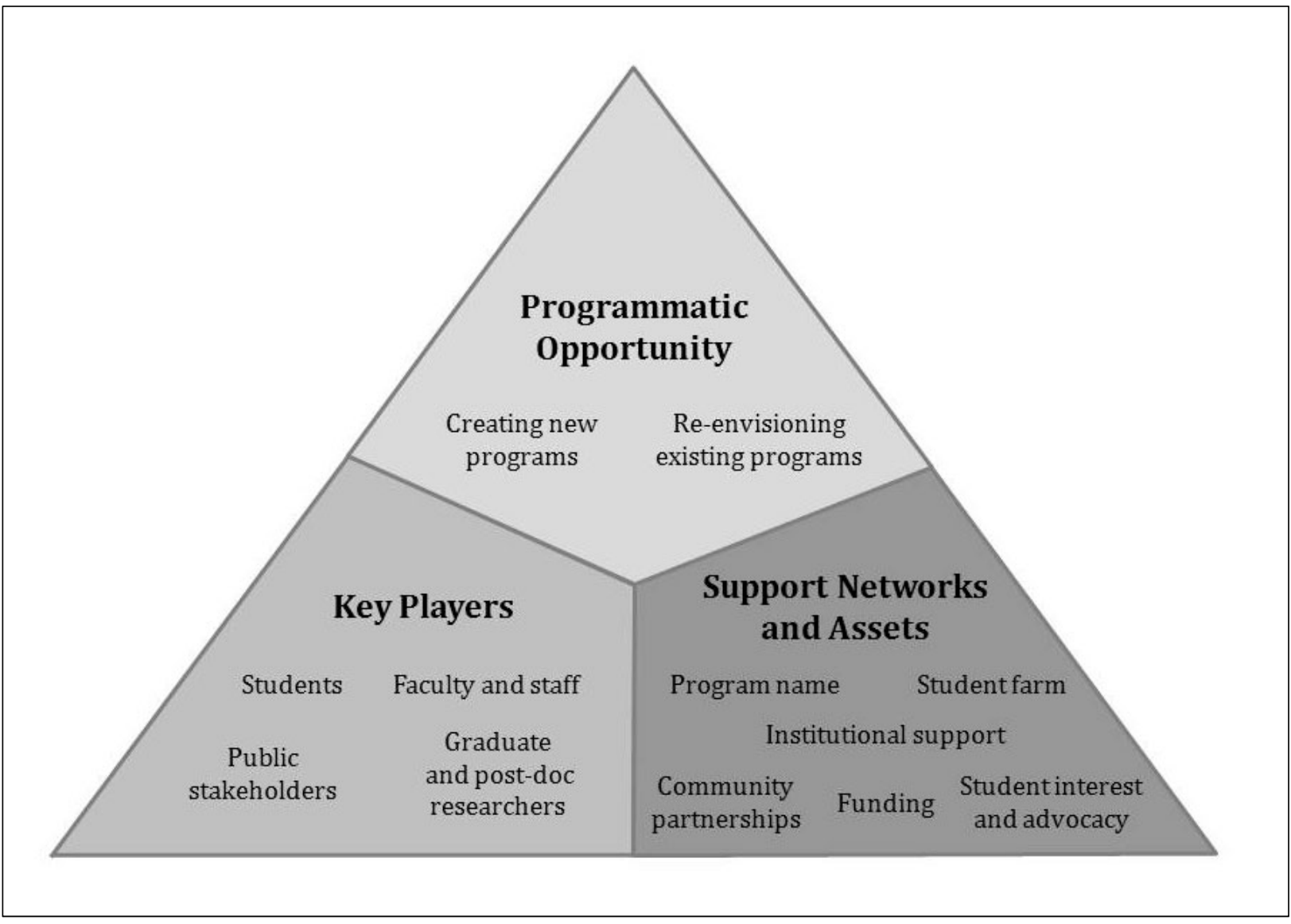

development opportunities: (1) to re-envision an existing major or minor and replace the traditional program with an SA program(s), or (2) to create entirely new programming (figure 1).

Colleges of agriculture have been facing declining undergraduate enrollment, particularly in the plant and soil sciences, for a number of years (Hansen, Ward, Khosla, Fenwick, \& Moore, 2007). Declining enrollment in traditional majors and feedback from stakeholders (e.g., current students, alumni, farmers, and industry representatives) provided sufficient rationale for the revision of existing programming to incorporate more emphasis on holistic, interdisciplinary subject matter. Thus existing programs with declining enrollment were collapsed and the curriculum retooled to incorporate new curricular goals and replaced with an SA-oriented degree program (e.g., an "Agronomy" degree is replaced with "Agroecology."). SA programs that were designed to replace or augment existing undergraduate degree programs include the Agroecology majors at Penn State (Karsten \& Risius, 2004) and the University of Wyoming (S. Herbert, personal communication, October 25, 2011).

The majority of the SA programs represented in table 1 were designed as new curricula to be offered in addition to traditional undergraduate degree programs rooted in both the natural and social sciences. These new programs were designed to draw from current courses from multiple departments and units, including agricultural economics, agricultural sciences, agronomy, animal sciences, crop and soil sciences, entomology, horticulture, human nutrition, plant pathology, and 
rural sociology, as indicated by preconference participants. Existing courses in these areas are augmented with novel core SA courses and experiential learning opportunities unique to the SA program.

\section{Building Support Networks and Assets} for Creating $S A$ Programs at LGUs

Irrespective of the motivations for their creation and inclusion of existing discipline-specific coursework, SA curricula are distinctly different from traditional discipline-oriented agricultural curricula, in that they emphasize holistic analysis of food and agricultural systems, experiential learning, engagement with community practitioners, and an explicit integration of the social and natural sciences (Francis, 2009). Although SA programs are often created as "alternatives" to traditional degree programs, successful creation of SA programs requires support of key traditional constituencies due to the unique nature of the LGU mission and academic structure. In this section, we discuss a suite of support networks and assets that were essential to the development of the programs included in this work, presented in figure 1. Support for the development of new programs comes in the forms of physical capital, such as funding and land for student farms, as well as social capital, such as that created from building support for new programs from within the landgrant constituency.

\section{Community-university partnerships are} integral to the success of LGUs due both to the nature of SA curricula as well as the outreach mission of the LGU. As we discuss in an article in this issue on civic engagement (Niewolny, Grossman, Byker, Helms, Clark, Cotton, \& Jacobsen, 2012), partnerships with local organizations, farmers and other stakeholders greatly enrich SA curricula, as community partners perform as educators and mentors in student development. In the SA programs reviewed in this work, community advisory panels have been integral to the creation of some SA programs. Community partners have contributed to program development in several ways, including by partnering on federal competitive grants to fund program creation (e.g.,
Virginia Tech (S. Clark, personal communication, August 3, 2011)), by providing formal input on curriculum development in the form of key community members serving on advisory panels (e.g., Montana State), by participating in surveys (e.g., Penn State and UC-Davis (Karsten \& Risius, 2004 ; Parr et al., 2007)), and by providing informal feedback through conversations with farmers and industry (e.g., University of Kentucky and University of Florida (R. Darnell, personal communication, October 13, 2011)). As programs develop and students matriculate, community partners become key players in hosting students for service learning activities, internships, and as future employers.

Colleges of agriculture at LGUs may be the only arm of the university with a direct responsibility to engage the public (NRC, 2009, p. 20). Workshop participants noted a sense of duty to cultivate positive relationships with key community partners, such as local farmers, industry, and state agencies. In particular, public stakeholder input has been used to structure the nature and scale of student farms so as not to compete with local farmers, to contribute work sites and skills for internship requirements, and to contribute to the process of selecting a program name.

Program identity has been recognized as a central asset of SA programs nationally that generates morale and a sense of community (Ngouajio et al., 2006). In the workshop discussion, participants noted that selection of names served to both divide and include various groups in the creation of the programs. For example, the term "sustainable" could invoke the implication that previous programming was "unsustainable" to public stakeholders and colleagues within the LGU. To avoid potential conflict, programs have chosen names that incorporate a natural science-oriented perspective such as "agroecology," or that specifically draw boundaries on curriculum, such as "organic" programs that are rooted in the USDA National Organic Program with a delineated set of practices. In other cases, the inclusion of "food systems" or "civic agriculture" in a program title illustrated a significant social discourse underlying the creation of the programs and explicitly values the contributions of community practitioners and 
social scientists (e.g., Virginia Tech's Civic Agriculture and Food System Minor, the University of California-Davis's Sustainable Agriculture \& Food Systems Major, and Montana State University's Sustainable Food and Bioenergy Systems Major). The process of creating an identity has the potential to be either divisive or communitybuilding within the LGU itself and the external public constituency. Ultimately the name of SA programs creates a unique branding for programs that sets SA programs apart from the traditional, existing programs.

Student interest in curricula focused on experiential learning in alternative agriculture systems has been a hallmark in creating and perpetuating SA programs throughout the country. Student interest in developing SA programming is most visible in extensive student involvement in the development of student farms. Students have been integral in developing student farms and gardens at LGUs across the country, including Maine (Sarrantonio, 2011), California (Parr \& Van Horn, 2006; Van Horn, 2011), Michigan (Biernbaum, Jgouajio, \& Thorp, 2006), Florida (X. Zhao, personal communication, October 13, 2011), and North Carolina (M. Schroeder-Moreno, personal communication, November 30, 2011). As discussed by Parr and Trexler (2011), student farms also create a sense of place in programs, an important factor in student retention in SA programs. In fact, the creation of student farms has consistently predated SA programs, with student farm students acting as key initiators of SA curriculum at their respective campuses (Parr \& Trexler, 2011; Sayre, 2011). Inspired by their experiences on student farms, students have also been direct advocates for creating SA programs at LGUs and have been formally represented on committees working on program creation (Van Horn, 2011; Liebman, 1997).

Program funding. In general, programs that were re-envisionings of existing programming were created without the use of external competitive funds, but rather from a mandate within departments or the college of agriculture. Most of the programs created as new degrees to augment traditional agriculture programming were developed with the support of external, competitive funding. These include regional U.S. Department of Agriculture (USDA) Sustainable Agriculture Research and Education (SARE) program funds, foundation funding, and most commonly, USDA Higher Education Challenge Grants (see references to HECG in table 1). Further, of the $11 \mathrm{SA}$ programs represented in this work, eight were created to exist alongside traditional programming, and faculty actively sought external funding to support curriculum development efforts. Of these eight, five received HECG funding for activities directly related to creating SA programs. From this cohort of SA undergraduate majors and minor degree programs at LGUs, HECGs appear to be an effective and widespread funding mechanism for these efforts.

Institutional support. SA programs reviewed here are largely defined as interdisciplinary, interdepartmental programs, requiring support from diverse discipline-oriented departments, including agricultural economics, agronomy, agricultural education, animal science, human nutrition, horticulture, and rural sociology, to name a few. Workshop participants stated that the support from various departments within the colleges of agriculture varied, with some interdepartmental partnerships happening from the outset, to others that have resisted supporting ongoing SA programs for various reasons. When creating alternative programming, faculty can receive institutional legitimacy for their curriculum development work by tying to traditional reward structures in the LGU system. For example, faculty have who have taken on the development of new curriculum and coursework have in some cases begun with exploratory research, needs assessments, or Delphi surveys of experts and stakeholders, and have disseminated case studies of their courses, program components or novel teaching methodologies through peer-reviewed manuscripts (Biernbaum, Jgouajio, \&Thorp, 2006; Delate, 2006; Falk, Pao, \& Cramer, 2005; Ferguson, Lamb, \& Swisher, 2006; Harmon, 2002; Jordan, Andow, \& Mercer, 2005; Karsten \& Risius, 2004; Markhart, 2006; Parr \& Van Horn, 2006; Parr et al., 2007; Perillo, JohnsonMaynard, Ater-Kranov, Harmon, Mavrolas, \& Koenig, 2010; Schroeder, Creamer, Linker, Mueller, \& Rzewnicki, 2006; Trexler, Parr, \& Khanna, 2006; 
Wharton \& Harmon, 2009). Similarly, externally funded grants are nearly always positive additions to curriculum vitae, and provide the tenure and promotion review committee with evidence that a faculty member is doing work that is respected by the profession. Ultimately, the programs reviewed in this work were able to garner sufficient internal institutional support for their creation. In some cases, easy partnerships were created between departments, and curriculum development efforts were supported at the college administrative level. However, building constituency and institutional support within colleges of agriculture and some stakeholder groups continues to be a challenge for some SA programs, as discussed below.

\section{Current Challenges and Opportunities}

This article focuses on many successes of SA programs at land grant universities, but there remain a number of challenges for both existing and developing programs. While challenges can be impediments to progress, they can also help us understand how to improve our efforts and identify new and better ways forward. A few of the common challenges and related opportunities associated with SA programs at LGUs are described here.

Philosophical and political challenges. The study of sustainable agriculture, by its nature, includes examining both the positive and negative environmental, social, and economic impacts of agriculture as a system of production, distribution, and consumption. These examinations often acknowledge and explore the environmental and social challenges associated with conventional agricultural systems. These kinds of examinations have been resisted by individuals and organizations both inside and outside some LGUs for various reasons, thus limiting the development of SA academic programs at some institutions. In addition, a number of LGUs have struggled to maintain viable numbers of students enrolled in their production-based agricultural programs (Hansen et al., 2007). The development of new SA programs is seen by some as a potential solution to this problem, but others see it as competing with and undermining more traditional curricula. How- ever, LGUs have the opportunity to create programs and courses that integrate students with both traditional and nontraditional backgrounds and interests and thus help develop within all students a shared understanding and appreciation of different approaches to agriculture. We posit that development of future SA programs at our peer institutions may be expedited by assessing the institutional landscape for key elements present in successfully established SA programs. Research investigating the root causes for why these elements may be lacking would contribute to the literature on systemic barriers to SA program creation at LGUs, and bring these issues to the forefront of the dialogue on SA education at LGUs.

Administrative support for interdisciplinary interdepartmental programs. An understanding of SA requires both disciplinary and interdisciplinary studies, drawing from many faculty in diverse natural and social science disciplines. While the departmental homes of SA programs range widely at different LGUs, all SA programs must depend on courses and teaching efforts that cross multiple departments. Faculty teaching assignments and related resource allocations are typically controlled at the departmental level and, within an institution, different departments have different programmatic priorities and may exhibit differing levels of support for a SA program. These factors contribute to the complexity of coordinating SA teaching and advising assignments across departments. Strong college and/or university administrative support and communication among department leaders are needed to support existing faculty members' teaching efforts across departments. New faculty hires with specific SA teaching responsibility may be required to ensure the successful development and longevity of SA programs.

Adequate facilities and resources to support experiential leaning. Understanding SA requires interdisciplinary and integrative studies of systems, which in turn require experiential and field-based learning opportunities such as laboratories, field trips, and internships. Such learning modalities are resource-intensive and may involve the use of special facilities, such as a student farm 
(Parr \& Van Horn, 2006). Many SA programs are using innovative educational strategies to engage students in experiential learning activities through student farms, intensive internship programs (as discussed by Schroeder-Moreno, Clark, Byker, \& Zhao, in this issue), or other means; these in turn necessitate adequate funding and personnel to be successful.

\section{Expanding faculty teaching expertise} beyond their traditional disciplinary training. Traditionally, new faculty at LGUs are likely hired from graduate programs focused on research and teach courses within their discipline (e.g., a soil scientist would be expected to teach Introduction to Soils). Faculty teaching SA programs frequently must learn and/or synthesize new academic material in order to offer a quality learning experience for students. Teaching upper division courses, including capstone courses, where materials do not necessarily exist or practical projects dominate the syllabus, pose a new challenge. The instructor may not have any particular expertise to apply, and therefore must exercise a new set of teaching skills that might include facilitation or providing guidance for professional development.

Balancing breadth and depth, and instructing within a new discipline. The relative newness of SA education as a discipline together with the lack of shared instructional materials make it challenging for instructors, especially for the many junior faculty teaching and directing in these programs. While communication about shared resources and pedagogy are developing with the SAEA, this newness, combined with the wide breadth of the SA as a discipline, create challenges in teaching students about sustainable agriculture, such as determining the limits of what will be included in a course or program. Adequately teaching the depth of the multidisciplinary topics within SA poses a difficult challenge for a single instructor, yet this presents opportunities for crossdisciplinary teaching efforts through guest lecturers or cross-listed courses. Students can benefit greatly from diverse perspectives and expertise when SA courses and programs engage faculty from various disciplines.

Risks in instruction and course development. The experiential and interdisciplinary nature of SA programs may require instructors from traditional research backgrounds to stretch beyond their research and teaching training. Learning new content and instructional skills and researching pedagogical approaches create an exciting opportunity for the instructor, but require time and effort. This should be both emphasized and detailed in one's dossier, with special attention given to the novel approaches used in coursework. Risk-taking is inherent in sustainable agriculture and food systems teaching, and its results are reflected in students' course and instructor evaluation scores. If an experimental aspect of a course does not go well, student reviews may be lower, and vice versa. Since scores are often used as evidence in the tenure and promotion review, faculty should take this into account and be reflective when composing a selfevaluation and teaching philosophy for the dossier. It is often helpful to incorporate additional forms of formative and summative evaluation in new courses that use novel teaching methods, as well as peer evaluation of instruction and content, to both better inform a self-evaluation and provide additional written evidence for professional evaluation.

Balancing faculty efforts in SA instruction with other expectations. It was a timely moment at the workshop when conference attendees were asked "who here is tenured?" and only three of the 10 tenure-track faculty members raised their hands. The enthusiasm and passion of pre-tenured faculty can be significant sources of energy for the development of SA programs, but they can be challenged considerably in balancing developing new interdisciplinary programs and expectations for tenure. New faculty should become well acquainted with both documented and undocumented expectations, work hard to develop collegial relationships with faculty within and across departments, including those outside of sustainable agriculture and with administrators, and understand what is recognized as academic scholarship at their individual institution (Boyer Commission, 1998; Finkelstein, 2001). While pretenured faculty leading these SA programs face challenges that are considerable and diverse, many opportunities exist for interdisciplinary collaborations in research, instruction, and outreach within 
and across departments and institutions. Moreover, pre-tenured faculty can learn from and be supported through these collaborations by informal and formal mentoring of tenured faculty. It may be a worthy activity for the Sustainable Agriculture Education Association to establishing a cadre of mentoring faculty who have been tenured and promoted successfully and who offer to provide support for junior faculty.

\section{Conclusion and Recommendations for Future LGU Program Development}

Within the national landscape of SA programs in higher education, LGUs have a unique role and obligation to stakeholders and students to provide SA educational opportunities. The programs reflected in this work emerged out of a combination of the right timing for development of SA curriculum, supporting social capital and financial resources, and having a suite of passionate players — faculty, staff, and students — who were vested in creating programs that are alternatives to traditional agricultural undergraduate degree programs and meet a changing agricultural paradigm. We have outlined the genesis of these programs, our shared challenges, and offered opportunities that might be used to overcome them. Specifically, we would like to offer the following recommendations to our colleagues at other LGUs considering creating SA programs.

\section{Recommendations for faculty and staff}

- Pursue research in the context of your sustainable agriculture teaching program. Find ways to authentically apply the concept of "engaged scholarship" by integrating work on course development into your teaching efforts within the traditional evaluation and reward structure of the LGU.

- An increasing number of agriculture venues are encouraging of service-learning, experiential, and interdisciplinary teaching approaches and applications. Seek professional development opportunities to learn "best practices" at venues relevant to your institution and program.
- Proactively reach out to community members, especially farmers, and seek their input on structure and content of courses and curricula. Creating an advisory panel or other mechanism can help to formalize the feedback structure and be useful for grant-writing efforts.

- Students are often your best advocates for program generation and success. Steer youthful enthusiasm to learn about sustainable agriculture concepts and practices by way of critical reflection and engaged dialogue with peers.

- Be careful to balance time with SA program development and related service and outreach with your other faculty obligations. Seek mentorship with tenured faculty and supportive administrators to ease the work-load tension as well as to share teaching and programmatic responsibilities with contributing faculty members.

\section{Recommendations for students}

- Advocate for program development with your professors and university leadership. Understand the interests, needs, and concerns of faculty and administrators and strive to develop approaches that simultaneously further their agendas and yours. Develop and nurture good working relationships with faculty and administrator allies.

- Pursue coursework and research opportunities within the area of SA. Opportunities for both efforts are emerging and could have great impact on your academic and professional growth.

- Student farms and school gardens are often the center piece of SA programs. Seize opportunities to build these farms and gardens as student-driven initiatives.

- SA students are often perceived as part of a cohort of students who are "different" from other students in traditional majors in colleges of agriculture. Work to build the SA student community by participating in student clubs and informal activities with your peers. A vibrant student community aids in student retention and helps recruit new students into 
nascent programs, especially those with small numbers of students.

The content and conclusions of this paper are a function of the discreet cohort of SA undergraduate degree programs (majors and minors only), which was by design a narrow subset of SA programming in higher education. Even within the LGU system, there are a number of other programmatic structures, including concentrations, certificate programs, individual courses, and research opportunities in SA. Some of the experiences and challenges outlined in this work are applicable to the general SA education experience; however, the structure and mission of the LGU is unique in the university system. As we advance our collective dialogue on the current state and future of sustainable agriculture education, we look forward particularly to feedback from colleagues, particularly at private universities and teaching colleges, to discuss the similarities and differences in their experiences.

\section{Acknowledgements}

We would like to acknowledge the faculty and staff from LGUs who were not able to attend the SAEA preconference workshop that this article emerged from, but who contributed programmatic information and kind support for this effort. These include Dr. Stephen Herbert at the University of Wyoming, Dr. Rebecca Darnell at the University of Florida, Dr. Heather Karsten at Pennsylvania State University, and Drs. Eric Gallandt and Marianne Sarrantonio at the University of Maine. We also are grateful for the support of our colleges and universities who have granted us the opportunity to collaborate. The comments of anonymous reviewers strengthened this manuscript, and we thank them for their efforts. Lastly, we thank our colleagues within the Sustainable Agriculture Education Association for supporting this project from start to finish.

\section{References}

Altieri, M. A., \& Francis, C. A. (1992). Incorporating agroecology into the conventional agricultural curriculum. American Journal of Alternative
Agriculture, 7, 89-93. http://dx.doi.org/10.1017/S0889189300004525

Biernbaum, J. A., Jgouajio, M., \& Thorp, L. (2006).

Development of a year-round student organic farm and organic farming curriculum at Michigan State University. HortTechnology, 16(3), 432-436.

Boyer Commission. (1998). Reinventing undergraduate education: A blueprint for America's research universities. Carnegie Foundation for the Advancement of Learning. Retrieved from http://naples.cc.sunysb.edu/Pres/boyer.nsf/

Delate, K. (2006). Incorporating organic and agroecological approaches into the university curricula: The Iowa State University graduate program in sustainable agriculture. HortTechnology, 16(3), 445-448.

Dewey, J. (1916). Democracy and education. New York: MacMillan Company.

Falk C. L., Pao P., \& Cramer, C. S. (2005). Teaching diversified organic crop production using the community supported agriculture farming system model. Journal of Natural Resources and Life Sciences Education, 34, 8-12.

Ferguson, J. J., Lamb, E. \& Swisher, M. (2006). Developing an interdisciplinary organic and sustainable agriculture curriculum at the University of Florida, HortTechnology, 16, 436-438.

Finkelstein, M. (2001). Toward a unified view of scholarship: Eliminating tension between tradition and engaged work. Journal of Higher Education Outreach and Engagement, 6, 35-44.

Francis, C. A. (2009). Education in organic farming and food systems. In C. A. Francis (Ed.), Organic farming: The ecological system (pp. 283-300). Madison, Wisconsin: Agronomy Society of America.

Francis, C. A., Jordan, N., Porter, P., Breland, T. A., Lieblein, G., Salomonsson, L.,...Langer, V. (2011). Innovative education in agroecology: Experiential learning for a sustainable agriculture. Critical Reviews in Plant Sciences, 30(1), 226-237. http://dx.doi.org/10.1080/07352689.2011.554497

Francis, C. A., Leiblein, G., Helenius, J., Salomonsson, L., Olsen, H., \& Porter, J. (2001). Challenges in designing ecological agriculture education: A Nordic perspective on change. American Journal of Alternative Agriculture, 16(2), 89-95. http://dx.doi.org/10.1017/S0889189300008985 
Francis, C. A., Lieblein, G., Gliessman, S., Breland, T. A., Creamer, N., Harwood, R.,... Poincelot, R. (2003). Agroecology: The ecology of food systems. Journal of Sustainable Agriculture, 22(3), 99-117. http://dx.doi.org/10.1300/J064v22n03 10

Galt, R. E., Clark, S. F., \& Parr, D. (2012). Engaging values in sustainable agriculture and food systems education: Toward an explicitly values-based pedagogical approach. Journal of Agriculture, Food Systems and Community Development. Advance online publication. http://dx.doi.org/10.5304/jafscd.2012.023.006

Hansen, N., Ward, S., Khosla, R., Fenwick, J., \& Moore, B. (2007). What does undergraduate enrollment in soil and crop sciences mean for the future of agronomy? Agronomy Journal, 99, 1169-1174. http://dx.doi.org/10.2134/agronj2006.0318

Harmon, A. H. (2002). Teaching sustainability using the food system as a model. In W. L. Filho (Ed.), Teaching sustainability at universities: Towards curriculum greening (pp. 239-249), Frankfurt: Peter Lang Publishing Group.

Jordan, N. R., Andow, D. A., \& Mercer, K. L. (2005). New concepts in agroecology: A service-learning course. Journal of Natural Resources and Life Sciences Education, 34, 83-89.

Karsten, H. D., \& Risius, M. L. (2004). Development of an interdisciplinary Agroecology major with input from surveys of students, graduates, and employers. NACT A Journal, 48, 58-64.

Kellogg Commission on the Future of State and LandGrant Universities. (1999). Returning to our roots: The engaged institution. Battle Creek, Michigan: W. K. Kellogg Foundation

LaMay, C. L. (2001). Justin Smith Morrill and the politics and legacy of the land-grant college acts. In L. K. Grossman \& N. N. Minow (Eds.), A digital gift to the nation: Fulfilling the promise of the digital and Internet age (pp. 73-95). New York: The Century Foundation Press.

Liebman, M. (1997). The University of Maine sustainable agriculture program: Factors in success. Consortium News (Consortium for Sustainable Agriculture Research and Education), 14, 5-6.

Markhart, A. H. III. (2006). Organic educational opportunities at the University of Minnesota: The role of a student-run organic farm. HortTechnology, 16(3), 443-445.

Morrill Act. (1862). Thirty-Seventh U.S. Congress, Session II, Chapter 130. Retrieved from http://www.memory.loc.gov/cgi-bin/ampage? collid $=$ llsl\&fileName $=012 / 1$ s1012.db\&rec$\mathrm{Num}=534$

National Research Council [NRC]. (1996). Colleges of agriculture at the Land Grant Universities: Public service and public policy. Committee on the Future of the Colleges of Agriculture in the Land Grant University System. Washington, D.C.: National Academy Press.

National Research Council [NRC]. (2009). Transforming agricultural education for a changing world. Washington, D.C.: The National Academies Press.

Ngouajio, K., Delate, E., Carey, A. N., Azarenko, J., Ferguson, J., \& Sciarappa, W. J. (2006). Curriculum development for organic horticulture: Introduction. HortTechnology, 16(3), 414-417.

Niewolny, K. L., Grossman, J. M., Byker, C. J., Helms, J. L., Clark, S. F., Cotton, J. A., \& Jacobsen, K. L. (2012). Sustainable agriculture education and civic engagement: The significance of communityuniversity partnerships in the new agricultural paradigm. Journal of Agriculture, Food Systems and Community Development. Advance online publication. http://dx.doi.org/10.5304/jafscd.2012.023.005

Parr, D., \& Van Horn, M. (2006). Development of organic and sustainable agricultural education at the University of California, Davis: A closer look at practice and theory. HortTechnology, 16(3), 426-431.

Parr, D., Trexler, C. J., Khanna, N. R., \& Battisti, B. T. (2007). Designing sustainable agriculture education: Academics' suggestions for an undergraduate curriculum at a land-grant university. Agriculture and Human Values, 24, 523-533. http://dx.doi.org/10.1007/s10460-007-9084-y

Parr, D. and Trexler, C.J. (2011). Students' experiential learning and use of student farms in sustainable agriculture education. Journal of Natural Resources and Life Science Education. 40,172-180.

Perillo, C. A., Johnson-Maynard, J., Ater-Kranov, A., Harmon, A. H., Mavrolas, P., \& Koenig, K. (2010, October 31-November 1). Developing a regional learning community around teaching sustainable food and agricultural systems at the university level. Poster abstract 
presented at the annual meetings of the American Society of Agronomy, Long Beach, California.

Sarrantonio, M. (2011). University of Maine: Majoring in sustainable ag. In L. Sayre \& S. Clark (Eds.), Fields of learning: The student farm movement in North America (pp. 173-191). Lexington, Kentucky: The University Press of Kentucky.

Sayre, L. (2011). Introduction: The student farm movement in context. In L. Sayre \& S. Clark (Eds.), Fields of learning: The student farm movement in North America (pp. 1-30). Lexington, Kentucky: The University Press of Kentucky.

Schroeder-Moreno, M. S., Clark, S. F., Byker, C. J., \& Zhao, X. (2012). Internationalizing sustainable agriculture education. Journal of Agriculture, Food Systems and Community Development. http://dx.doi.org/10.5304/jafscd.2012.023.007

Schroeder, M. S., Creamer, N. G., Linker, H. M., Mueller, J. P. \& Rzewnicki, P. (2006). Interdisciplinary and multilevel approach to organic and sustainable agriculture education at North Carolina State University. HorTechnology, 16(3),418-426.

Sustainable Agriculture Education Association [SAEA]. (n.d.-a). Promoting the teaching and learning of sustainable agriculture. Retrieved from http://www.sustainableaged.org/About/tabid/56/ Default.aspx
Sustainable Agriculture Education Association [SAEA]. (n.d.-b). Academic programs. Retrieved from http://sustainableaged.org/Resources/Academic Programs/tabid/86/Default.aspx

Trexler, C. J., Parr, D. M., \& Khanna, N. (2006). A Delphi study of agricultural practitioners' opinions: necessary experiences for inclusion in an undergraduate sustainable agricultural major. Journal of Agricultural Education, 47, 15-25. http://dx.doi.org/10.5032/jae.2006.04015

United States Department of Agriculture [USDA]. (2009). National Agricultural Library educational and training opportunities in sustainable agriculture (19th ed.). USDA-ARS, Beltsville, Maryland. Retrieved from http://www.nal.usda.gov/afsic/pubs/edtr/ EDTR2009.shtml

Van Horn, M. (2011). Moving from the margins to the center. In L. Sayre \& S. Clark (Eds.), Fields of learning: The student farm movement in North America (pp. 129148). Lexington, Kentucky: The University Press of Kentucky.

Wharton, C., \& Harmon A. H. (2009). University engagement through local food enterprise: Community supported agriculture on campus. Journal of Hunger and Environmental Nutrition, 4, 112-128. http://dx.doi.org/10.1080/19320240902915235 